\title{
Glacial thermohaline circulation states of the northern Atlantic: the compatibility of modelling and observations
}

\author{
G. R. BIGG ${ }^{1}$, M. R. WADLEY ${ }^{1}$, D. P. STEVENS ${ }^{2}$ \& J. A. JOHNSON ${ }^{2}$ \\ ${ }^{1}$ School of Environmental Sciences, University of East Anglia, Norwich NR4 7TJ, UK \\ ${ }^{2}$ School of Mathematics, University of East Anglia, Norwich NR4 7TJ, UK
}

\begin{abstract}
Observational evidence from deep-sea cores suggests that the ocean circulation during the last glacial cycle was highly variable, at times occupying states very different from those found today. Modelling can be used to dynamically constrain the possible circulation states compatible with observations, thus guiding both understanding of past climate but also the geographical and scientific thrust of future palaeoceanographic research. The Last Glacial Maximum has been extensively studied and here, using carbon isotopes, among other variables, the most likely thermohaline state consistent with palaeoclimatic data is constructed. Past and new modelling efforts for the Last Glacial Maximum are then examined, to contrast questions resolvable by the modelling/data comparison with those that remain unanswered. This shows modelling evidence to confirm the prevailing view of intermediate-depth North Atlantic Deep Water being produced at the Last Glacial Maximum, in combination with deep water production around Antarctica. The potential sites for this deep and intermediate water production are defined by the basic state of the thermohaline circulation. However, their relative importance is a function of small perturbations in the surface temperature and salinity fields brought about by active coupling between the ocean and atmosphere. Regions where these water masses may have been produced at the Last Glacial Maximum are suggested.
\end{abstract}

Keywords: Pleistocene, North Atlantic, thermohaline circulation, models, carbon isotopes.

The state of the thermohaline circulation of the ocean at the Last Glacial Maximum has proven to be a source of controversy for palaeoceanographers. Within the last decade three rather different concepts of the thermohaline circulation have been presented as being consistent with some aspects of palaeoceanographic evidence. One of these describes an ocean whose depths are dominated by water of Antarctic origin, called Southern Component Water, with almost complete cessation of production of North Atlantic Deep Water (Oppo \& Fairbanks 1987). A second hypothesis has also been presented, of the inverse scenario of strong Noth Atlantic Deep Water production and an isolated Southern Ocean (Imbrie et al. 1992). The third hypothesis, of North Atlantic Deep Water sinking to intermediate depth and feeding into the Circumpolar Deep Water of the Southern Ocean, but with the deep waters of all ocean basins dominated by Sothern Component Water (Boyle 1992), is currently gaining the most widespread support (see Boyle 1997 for a review). It contains a number of uncertainties however, over the strength of production, and extent of southward penetration, of North Atlantic Deep Water, the location of deep water formation in the North Atlantic and Southern Ocean, the degree of northward heat transport within the North Atlantic and the presence of intermediate water formation in the NW Pacific. This paper will explore some of these points further in the next section in order to set the scene for discussion of how previous ocean modelling work may help in reconciling the palaeoceanographic evidence. The paper then considers a suite of new global ocean simulations of the Last Glacial Maximum, and discusses their implications for the dynamical balances consistent with observations for this period. The paper concludes with a discussion of the consequences of a comparison between the modelling results and observational evidence for the state of the Last Glacial Maximum thermohaline circulation.

\section{The thermohaline circulation at the Last Glacial Maximum}

One major means of investigating the thermohaline circulation of the global ocean is through the distribution of chemical tracers. While a number are available that can be observed in both the modern ocean and the past, the latter through foraminiferal records, many more observations exist of the ratio of the ${ }^{13} \mathrm{C}$ to ${ }^{12} \mathrm{C}$ isotopes $\left(\delta^{13} \mathrm{C}\right)$ than of other potential tracers (Boyle 1992). These observations are heavily biased towards the Atlantic, partly because of the intrinsic interest in the Atlantic, the location of the major downwelling components of the thermohaline circulation, but also because most palaeoceanographers are located around the shores of this ocean. While interpretation of $\delta^{13} \mathrm{C}$ is not straightforward (Boyle 1997), it contains considerable information on the surface properties from whence the deep and intermediate waters originated. Because these original surface waters tend to be cold the temperature-dependent fractionation of ${ }^{13} \mathrm{C}$ to ${ }^{12} \mathrm{C}$ between atmospheric carbon dioxide and the upper oceanic carbon reservoir (which we can loosely call $\Sigma \mathrm{CO}_{2}$ ) is a smaller part of the $\delta^{13} \mathrm{C}$ signal of sub-surface water. The major part of the signal is due to the preferential absorption of ${ }^{12} \mathrm{C}$ relative to ${ }^{13} \mathrm{C}$ from sea-water during photosynthesis (Broecker \& Peng 1982). Thus deep water that is nutrient-depleted, due to enhanced primary productivity in the surface waters from which it derived, has a higher $\delta^{13} \mathrm{C}$ value than nutrientenriched water. Thus North Atlantic Deep Water, originating in a nutrient-poor region tends to have high $\delta^{13} \mathrm{C}$ values, while Southern Component Water, coming from the nutrient-rich Southern Ocean, has low $\delta^{13} \mathrm{C}$. Changes in overturning strength, and the relative density of North Atlantic Deep Water compared to Southern Component Water, are thus discernible in the depth of the core of each water mass, and 

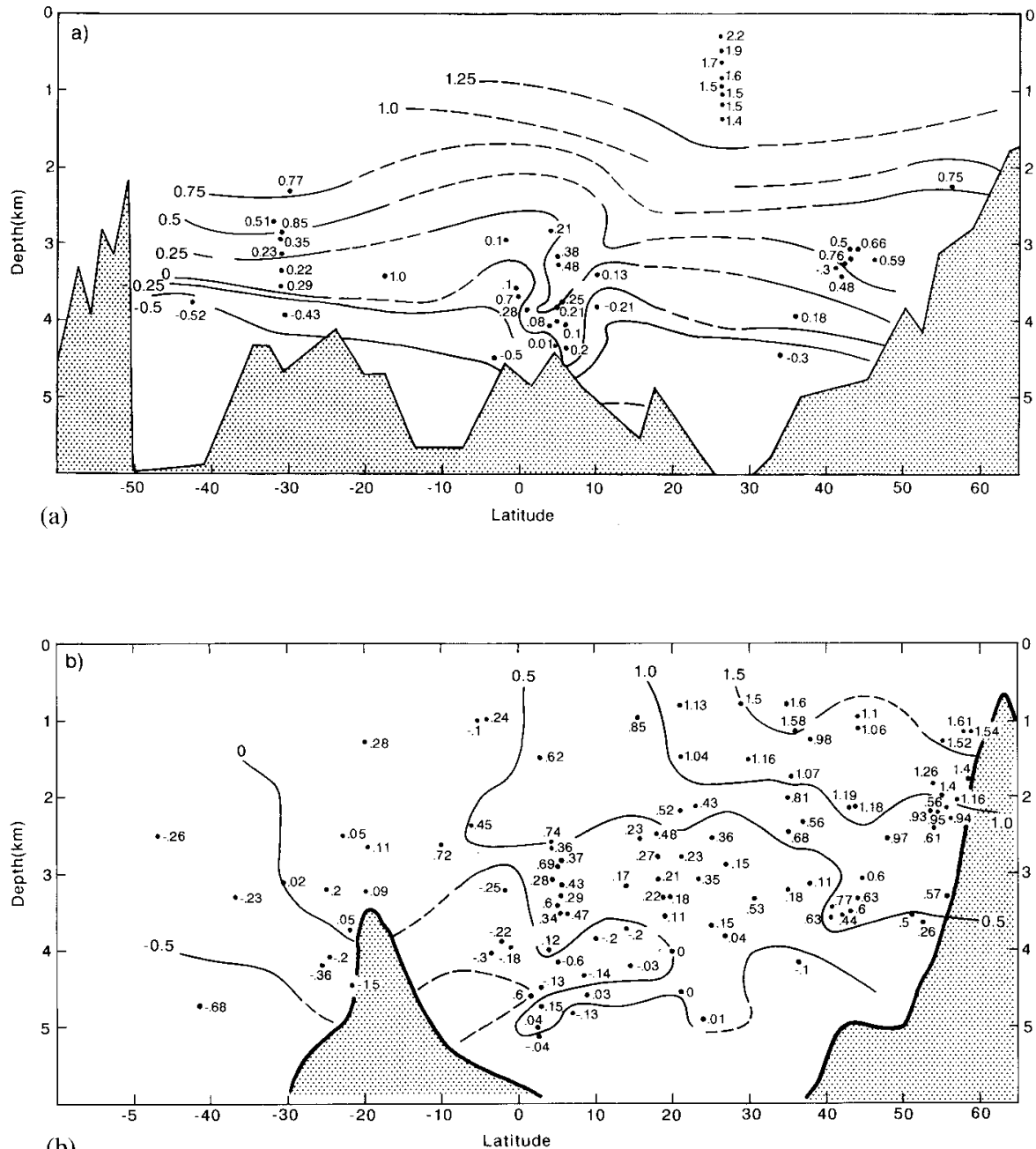

(b)

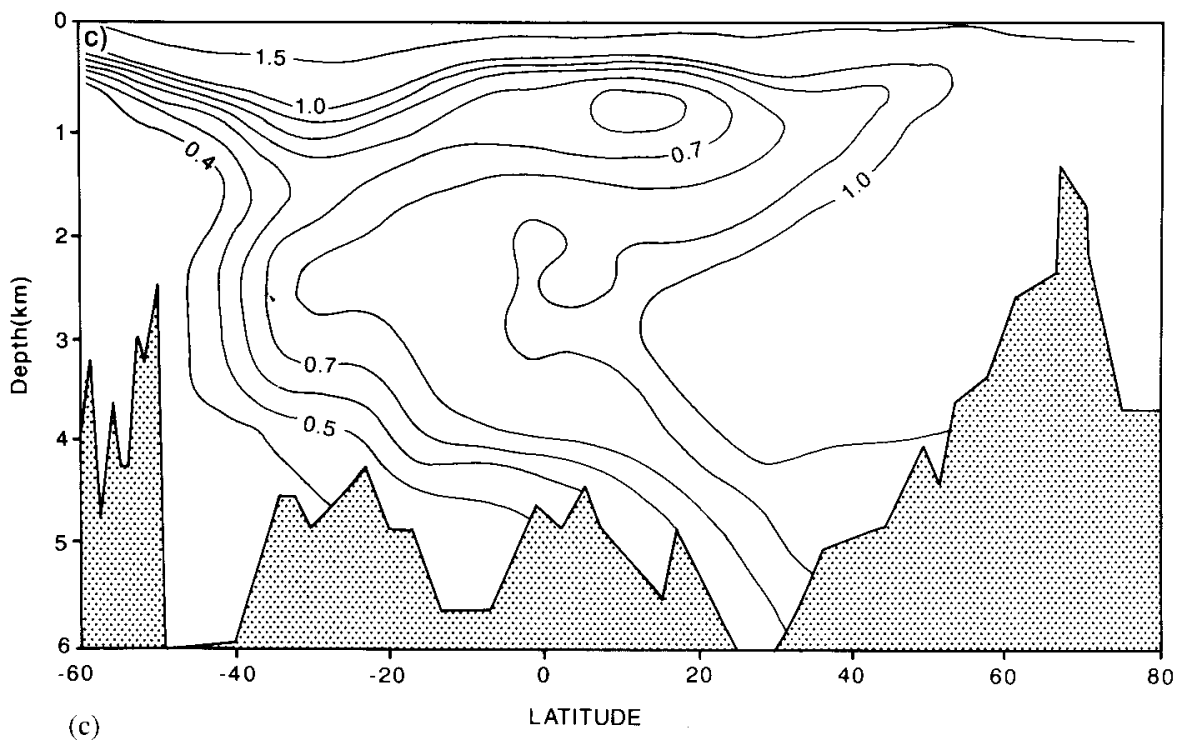

Fig. 1. Distributions of $\delta^{13} \mathrm{C}(\% 0)$ in C. wuellerstorf $i$ at the Last Glacial Maximum in (a) the western Atlantic basin and (b) the eastern Atlantic basin For comparison, modern sections are given for (c) the western Atlantic (adapted from Kroopnick 1985) and (d) the eastern Atlantic (core top $\delta^{13} \mathrm{C}$ ). In the Last Glacial Maximum figures, (a) and (b), $\delta^{13} \mathrm{C}$ values greater than $0 \%$ essentially denote North Atlantic Deep Water; in (c) and (d) the approximate boundary is $0.75 \%$. The data from which the sections (a), (b) and (d) have been compiled are from Curry \& Lohmann (1982), Boyle \& Keigwin (1987), Duplessey et al. (1988), Boyle (1992), Sarnthein et al. (1994), Slowey \& Curry (1995), Beveridge et al. (1995), Bertram et al. (1995), Berger \& Wefer (1996), Curry (1996), Bickert \& Wefer (1996), and Vidal et al. (1997). 


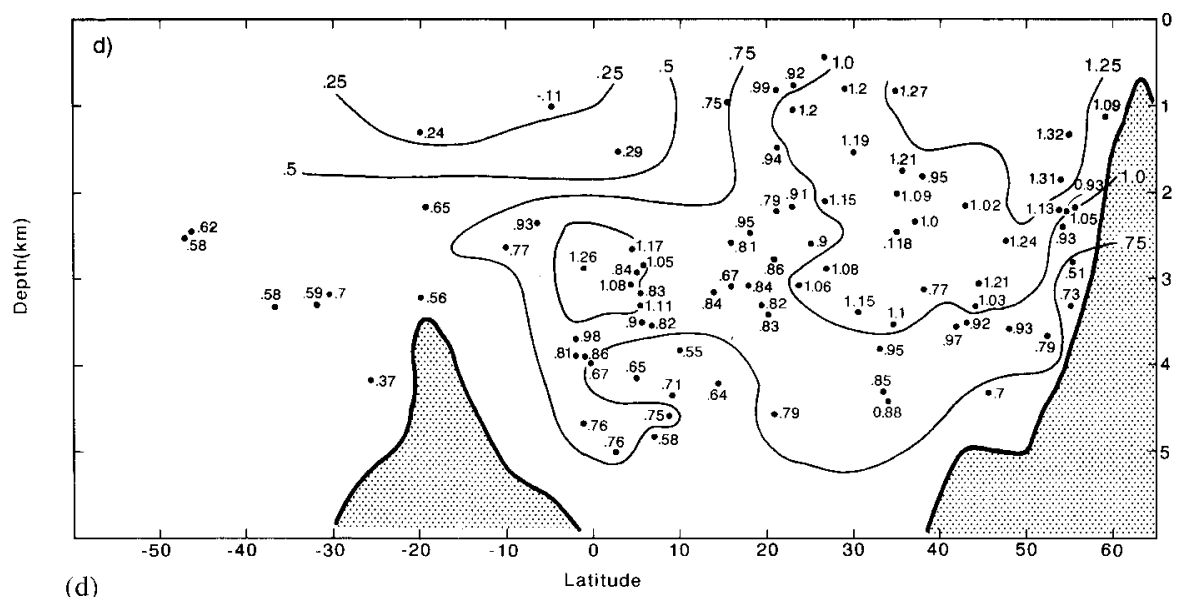

Fig. 1(d).

its penetration into the hemisphere in which it was not produced.

Within the Atlantic Ocean the most extensive palaeoceanographic evidence for the state of the thermohaline circulation at the Last Glacial Maximum exists in the eastern Atlantic where compilations of benthic $\delta^{13} \mathrm{C}$ by Duplessey et al. (1988) and Sarnthein et al. (1994) show a distinct signature of nutrient-poor North Atlantic Deep Water spreading south, to a depth of about $3500 \mathrm{~m}$, underlain by nutrient-rich Southern Component Water filling the deep waters of the whole eastern basin. This North Atlantic Deep Water looses most of its nutrient-poor signature by $20^{\circ} \mathrm{S}$. The contrast between the $\delta^{13} \mathrm{C}$ of the two Last Glacial Maximum water masses is some $2 \%$, compared to about $0.6 \%$ today. Boyle \& Rosenthal (1996) ascribe some of this difference to depletion in benthic foraminiferal $\delta^{13} \mathrm{C}$ in regions of high vertical fluxes of carbon (Mackensen et al. 1993) in the Southern Ocean, but this bias merely highlights the difference in path of the two water masses. The western Atlantic has been less well studied, but shows a clearer water mass signal in modern $\delta^{13} \mathrm{C}$ measurements of $\mathrm{\Sigma CO}_{2}$ (Kroopnick 1985), so a compilation of meridional sections of Last Glacial Maximum $\delta^{13} \mathrm{C}$ in the benthic foraminifer Cibicidoides wuellerstor $f$ in both basins has been carried out. In the eastern Atlantic Sarnthein et al.'s (1994) dataset has been extended. These sections are shown in Fig. 1a and $\mathrm{b}$, with modern distributions shown in Fig. 1c and $\mathrm{d}$ for comparison. Kroopnick's (1985) data is shown for the western Atlantic (Fig. 1c) but more measurements of core-top foraminiferal $\delta^{13} \mathrm{C}$ are available in the eastern basin so it is this that has been shown in Fig. 1d. There is a slight positive bias of $0.07 \%$ in the $\delta^{13} \mathrm{C}$ of $C$. wuellerstorfi, compared to $\Sigma \mathrm{CO}_{2}$, (Duplessey et al. 1984) but this has been neglected.

With this additional Last Glacial Maximum data clear differences are discernible between the two basins. While the vertical boundary between North Atlantic Deep Water and Southern Component Water was around $3500 \mathrm{~m}$ in both basins (roughly denoted by the $0 \%$ isoline), North Atlantic Deep Water appears to have extended much further south in the western basin. It was still present in the latter in the vicinity of the Rio Grande Rise, at $30^{\circ} \mathrm{S}$. This difference between the basins is also present nowadays (with the North Atlantic Deep Water distinguished by $\delta^{13} \mathrm{C}$ being greater than about $0.75 \%$ ), but today's North Atlantic Deep Water tongue in the western basin has begun to mix with Antarctic Intermediate Water by this latitude, in contrast to the apparent situation at the Last
Glacial Maximum. This distribution argues for a strong flux of intermediate level North Atlantic Deep Water, perhaps similar to or somewhat greater than that of today, with mixing of the western basin's North Atlantic Deep Water into Circumpolar Deep Water in the Southern Ocean. Yu et al. (1996) previously showed that the Last Glacial Maximum Atlantic distribution of ${ }^{231} \mathrm{~Pa} /{ }^{230} \mathrm{Th}$ ratios implies significant advection of North Atlantic Deep Water into Circumpolar Deep Water, perhaps at a higher rate than today's. Boyle (1997) also argued for North Atlantic Deep Water penetration into the northern Indian Ocean at the Last Glacial Maximum on the basis of $\mathrm{Cd} / \mathrm{Ca}$ and $\delta^{13} \mathrm{C}$ evidence for nutrient depletion in these waters.

Additional evidence for more extensive transport of North Atlantic Deep Water in the western Atlantic basin during the Last Glacial Maximum is found in the resolution of some of the anomalies near the equator in Fig. 1. If all data between $0^{\circ}-10^{\circ} \mathrm{N}$ are plotted in a vertical cross-section across the Atlantic (Fig. 2), there is distinct evidence for transport of water through the Romanche Fracture Zone from the western basin to the eastern during both time-slices. In the eastern basin, Last Glacial Maximum North Atlantic Deep Water is essentially contained above the Mid-Atlantic Ridge while in the interior of the western basin the $0 \%$ contour is $500 \mathrm{~m}$ deeper. However, between 4500 and $5000 \mathrm{~m}$ on the eastern side of the Mid-Atlantic Ridge there is a region of anomalously high $\delta^{13} \mathrm{C}$ about $1000 \mathrm{~km}$ wide which is most likely to have come from a deep-intermediate level boundary current flowing south along the western side of the Ridge. The sill of the Romanche Fracture Zone is at a depth of $4350 \mathrm{~m}$, which is consistent with denser water flowing through and settling a few hundred metres deeper in the eastern basin. Eastward flow through the Romanche Fracture Zone occurs today (Mercier et al. 1994), and can be seen in Fig. 2b, but as a region of nutrient enrichment (that is lower $\delta^{13} \mathrm{C}$ ). Today's throughflow is of southern, rather than northern, origin. In the light of this analysis, one can also detect evidence for eastward flow through the Vema Fracture Zone (around $10^{\circ} \mathrm{N}$ ) in Fig. $1 \mathrm{~b}$ and d. The other piece of evidence in Fig. 2 for the more limited amount of Southern Component Water in the western basin is the suggestion of a nutrient-rich western boundary current along the South American coast, at higher levels than similar water in the middle of the basin. Curry (1996) noted this strong vertical contrast along the Ceara Rise, suggesting significant North Atlantic Deep Water production at the Last Glacial 


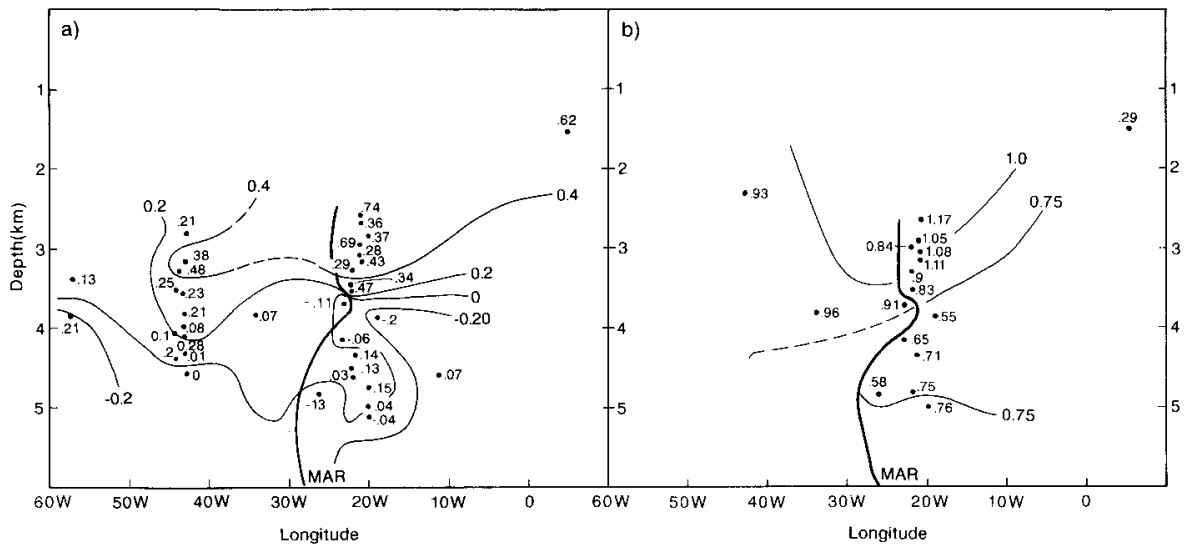

Fig. 2. Zonal cross-section of $\delta^{13} \mathrm{C}(\%)$ in C. wuellerstorfi along $5^{\circ} \mathrm{N}$ in the Atlantic (comprising all data from $0-10^{\circ} \mathrm{N}$ ) during (a) the Last Glacial Maximum and (b) the present day. Data taken from sources listed in the legend of Fig. 1. The Mid-Atlantic Ridge is denoted by a thicker line. Note that the longitude of the Mid-Atlantic Ridge varies with depth due to the latitude at which data from different depths derived.
Maximum. Radiocarbon ageing suggests that the deep Last Glacial Maximum Atlantic (Broecker 1989) and Pacific (Shackleton et al. 1988; Adkins \& Boyle 1997) were ventilated at about two thirds of today's rate, which requires some North Atlantic Deep Water formation unless Southern Component Water production was much greater than today.

The balance of observational evidence is therefore for production of North Atlantic Deep Water during the Last Glacial Maximum, of lower density than Southern Component Water, but at broadly similar rates to today's. The location of Last Glacial Maximum deep-water formation in both the North Atlantic and Southern Ocean is, however, not clearly established. Few data are available from the Southern Ocean to locate a deep-water source region. Boyle (1997) suggested that ice shelves would be less effective regions for deep-water formation during glacial periods, but Weber et al. (1994) showed evidence for strong down-slope currents in the southern Weddell Sea from Last Glacial Maximum laminated sediments. Michel et al. (1995) proposed possible open-ocean convection in the Indian Ocean sector.

In the North Atlantic there are more data, but inconclusive evidence for the location of intermediate-deep water formation. A major contributor to modern North Atlantic Deep Water, the Norwegian-Greenland Sea, is now thought to have been at least seasonally ice-free at the Last Glacial Maximum (Veum et al. 1992; Hebbeln et al. 1994; Sarnthein et al. 1995), suggesting significant northward transport of heat. However, the shallowness and restricted width of the sills at the Last Glacial Maximum, due to a $120 \mathrm{~m}$ sea-level lowering (Fairbanks 1989) and extensive ice cover on the islands across the Greenland-Iceland-Scotland Ridge (Peltier 1994), is generally thought to have prevented any dense water from entering the Atlantic proper (Labeyrie et al. 1992; Sarnthein et al. 1995). Nevertheless, Weinelt et al. (1996) reconstructed the density of the region and suggested that some deep water may have spilt over the ridge. Robinson \& McCave (1994) used sedimentation variability to suggest some Last Glacial Maximum deep-water formation in the Rockall Trough, which could be related to weak overflow. However, Manighetti \& McCave (1995), using grain-size measurements, inferred only weak currents leaving the Trough around Rockall Bank at the Last Glacial Maximum. This result suggests that any Last Glacial Maximum overflow was rather weak. The Labrador Sea in the NW Atlantic is also a source for modern North Atlantic Deep Water; Hillairemarcel et al. (1994) suggested this area was well ventilated at the Last Glacial Maximum, while Weinelt et al. (1996) postulated convection occurring south of Greenland on the basis of benthic $\delta^{13} \mathrm{C}$. Labeyrie et al. (1992), in reconstructing Last Glacial Maximum palaeodensities, also suggested that convection could have occurred in this region, although they located the formation region more in the central North Atlantic. Intermediate water formation in the sub-tropical Last Glacial Maximum North Atlantic has also been suggested by Slowey \& Curry $(1992,1995)$ and Labeyrie et al. (1992) on ventilation and density grounds respectively.

A key indicator for the location of Last Glacial Maximum convection in the North Atlantic is the value of surface-water $\delta^{13} \mathrm{C}$. Modern observations show clear evidence of continuity between surface-water values in the North Atlantic Deep Water formation regions and those in the tongue spreading southward in the Atlantic (Fig. 1c, Kroopnick 1985). We therefore need to locate, at the Last Glacial Maximum, the possible surface origins of intermediate waters (1000-2000 m) with a $\delta^{13} \mathrm{C}$ above $1.2 \%$, and a (probably) separate source for deeper waters $(2000-3500 \mathrm{~m})$ of approximately $0.8-1.0 \%$. The planktonic foraminifer Neogloboquadrina pachyderma is used to determine surface-water palaeo- $\delta^{13} \mathrm{C}$. Note that a correction factor of $+0.83 \%$ (Labeyrie \& Duplessey 1985) needs to be applied to the $N$. pachyderma $\delta^{13} \mathrm{C}$ to give a value appropriate for the surface-water $\Sigma \mathrm{CO}_{2}$ and comparable with the benthic values of $\delta^{13} \mathrm{C}$ derived from $C$. wuellerstorfi. Including this factor, Labeyrie \& Duplessey (1985), Hillairemarcel et al. (1994) and Sarnthein et al. (1995) all showed surface $\delta^{13} \mathrm{C}$ values in the Labrador Sea and SW of Iceland at around 1.0\%o at the Last Glacial Maximum. Similar values also occurred in the Norwegian-Greenland Sea (Sarnthein et al. 1995) but arguments above militate against any significant overflow. Over the Rockall Trough Sarnthein et al. (1995) showed a distinct minimum in Last Glacial Maximum planktonic $\delta^{13} \mathrm{C}$; neither intermediate nor deeper North Atlantic Deep Water can therefore come from this location. The deeper North Atlantic Deep Water in the Last Glacial Maximum Atlantic is therefore most likely to have come from the NW Atlantic.

The strongly nutrient-depleted upper North Atlantic Deep Water derives from another source, however, as no northern surface water has such high $\delta^{13}$ C. Slowey \& Curry (1992) found enhanced ventilation and high $\delta^{13} \mathrm{C}$ in the thermocline of the western Atlantic off the Bahamas $\left(26^{\circ} \mathrm{N}\right.$, Fig. 1b) while Sarnthein et al. (1994) presented similarly high $\delta^{13} \mathrm{C}$ in the thermocline of the eastern Atlantic off NW Africa $\left(30-35^{\circ} \mathrm{N}\right)$. Enhanced winter formation of sub-thermocline water across the sub-tropical Atlantic thus seems a likely mechanism for the origin of upper North Atlantic Deep Water at the Last Glacial 
Maximum. Labeyrie et al. (1992) also suggested this area was a possible location for intermediate water formation, although locating it near $40^{\circ} \mathrm{N}$. It is worth noting that a cross-section in $\delta^{13} \mathrm{C}$ across the Mid-Atlantic Ridge (Sarnthein et al. 1994) suggests an intermediate level (1000-1500 m), northwardflowing eastern boundary current carrying nutrient-poor water from an eastern Atlantic source.

\section{Previous ocean modelling of the Last Glacial Maximum}

It has been known for some time that global numerical ocean models are capable of reproducing very different thermohaline states due to changes in surface fluxes, particularly of fresh water (Bryan 1986; Marotzke \& Willebrand 1991; Rahmstorf 1996). This behaviour is also exhibited in coupled models that are given a perturbation in the freshwater flux of the ocean (Rahmstorf 1994; Manabe \& Stouffer 1995; Tziperman 1997; Rahmstorf \& England 1997). Bigg et al. (1998) have shown this to also be true at the Last Glacial Maximum. They took an equilibrium state with strong North Atlantic Deep Water formation and, upon a temporary imposition of a freshwater anomaly in the northern Atlantic, produced a stable state with significant Southern Component Water production but only limited North Atlantic Deep Water production, supplying intermediate rather than deep water. The results of oceanmodelling studies of the Last Glacial Maximum will thus depend critically on the poorly known heat and freshwater forcing of the surface. Reconciliation of model results and palaeoceanographic data is therefore particularly important before one can use an ocean model to speculate about the ocean climate at the Last Glacial Maximum in data-poor areas.

The first global ocean model of the Last Glacial Maximum was that of Lautenschlager et al. (1992) who forced a geostrophic ocean model with CLIMAP (1981) sea surface temperature fields, and momentum and freshwater fluxes from the palaeoclimate simulation of Lautenschlager \& Herterich (1990). This produced extremely strong convection in the Pacific and a total shut-down of North Atlantic Deep Water formation which clearly did not fit radiocarbon or $\delta^{13} \mathrm{C}$ data, but was consistent with one of the states produced by Marotzke \& Willebrand (1991), whereby a positive freshwater anomaly was imposed over the Atlantic and a negative one over the Pacific. This run thus revealed errors in the surface water balance of the palaeoclimate model used. Fichefet et al. (1994) ran a zonally averaged three-basin model using similar surface forcing except for salinity. The latter was imposed by using the reconstruction of Duplessey et al. (1991) over the surface Atlantic; most of the rest of the ocean surface was relaxed to modern salinities $(+1$ psu to allow for sea level lowering). This model produced a state with shallow and weak $(<2000 \mathrm{~m})$ North Atlantic Deep Water production around $40^{\circ} \mathrm{N}$, with similar Southern Component Water formation to today. Bearing in mind its simplifications, the simulation shows some similarity with the observational reconstruction in the last section in its gross features, but not in detail.

Another approach to modelling the North Atlantic at the Last Glacial Maximum is to use a regional, rather than global, model. This enables a higher resolution model to be run but has considerable drawbacks in the selection of boundary conditions at the open-ocean limits of the model (Wadley et al. in prep.). Either the boundaries must be open, where information about the density of the inflowing water must be specified, or closed, when a relaxation to some specified density field is required for at least 5o from the boundary. In both cases the simulation is ultimately hostage to the imposed density field at the boundary as the effects of the boundary penetrate into the interior of a model of the size of the North Atlantic within a few decades. This is a shorter time than any reasonable spin-up period for studying sub-surface waters. With open boundaries, incompatibilities develop between interior flow and inflow estimates within a century (Wadley et al. in prep.). With relaxation this does not occur (Seidov et al. 1996), but eventually the relaxation is likely to force the interior circulation as much as the surface forcing. Nevertheless, Seidov et al. (1996) were able to force a closed boundary North Atlantic geostrophic ocean model at the Last Glacial Maximum with reconstructed sea surface temperatures and salinities which halved the strength of deep convection, and shifted it to shallower depths of $2500 \mathrm{~m}$ in the NW Atlantic south of Greenland. They also found some shallower convection in the sub-tropics. Webb et al. (1997), in contrast, found that nearmodern ocean heat transports were required in their Last Glacial Maximum climate model in order to sustain both cooler tropical temperatures than CLIMAP (1981) and ice-free Nordic Seas.

\section{Simulations}

\section{Model details}

The ocean general circulation model used in this study derives from the Modular ocean model version of the Princeton code (Pacanowski et al. 1991), with a thermodynamic sea-ice model from Semtner (1976). It covers the globe at a horizontal resolution of $4^{\circ}$ of longitude by $3^{\circ}$ of latitude, and has 19 levels in the vertical, increasing in thickness with depth from $30 \mathrm{~m}$ at the surface to $500 \mathrm{~m}$ at depth. The DBDB5 topographic data-set (US Naval Oceanographic Office 1983) was used to determine the depth of each grid cell, with adjustments to ensure overflow sills are correct in depth to the nearest vertical grid point (although they may be too wide). In addition, the Peltier (1994) Northern Hemisphere ice sheet topography was used to determine the coastline in the full Last Glacial Maximum runs, with ocean depths shallower by $120 \mathrm{~m}$ (Fairbanks 1989). Full details of the mixing coefficients and accelerated timestepping are presented in Bigg et al. (1998). The latter enabled us to carry out millennial-scale runs. The model was initialized with the modern day Levitus et al. (1994) temperature and Levitus \& Boyer (1994) salinity; in some runs the latter was adjusted upward by 1 psu to reflect the lower sea level. It should be noted that ocean models have little sensitivity to such salinity changes compared to a similar temperature change.

The wind fields employed for simulations were annual means from either the present day control or the Last Glacial Maximum simulation of Hall et al. (1996). The model's heat and freshwater fluxes, however, were forced at the surface in two ways (see also Table 1). Some runs were forced by restoring surface temperature and salinity to prescribed fields. The restoring timescale of 30 days gives a thermal coupling strength of $30 \mathrm{~W} \mathrm{~m}^{-2} \mathrm{~K}^{-1}$ (the thermal coupling strength is the effective change in surface heat flux perceived by the ocean in response to a $1 \mathrm{~K}$ change in the surface temperature). Other runs were driven by the annual mean atmosphere from the simulations of Hall et al. (1996). This directly provided the wind stress, precipitation and solar heat flux, and by providing other surface fields enabled us to use bulk aerodynamic flux 
Table 1. Description of model experiments

\begin{tabular}{|c|c|}
\hline Experiment label & Description \\
\hline PDrelax & $\begin{array}{l}\text { Temperature and salinity at all surface grid boxes are relaxed to Present Day climatology with a } \\
\text { time scale of } 30 \text { days }\end{array}$ \\
\hline PDSouth & Surface ocean forced by annual average fields of modern climate model (Hall et al. 1996) \\
\hline PDLabrador & $\begin{array}{l}\text { As for experiment PDSouth but with a negative anomaly of } 1 \mathrm{~mm} \text { per day imposed for } 500 \text { years } \\
\text { in the precipitation over the North Atlantic }\left(42-75^{\circ} \mathrm{N}, 70^{\circ} \mathrm{W}-14^{\circ} \mathrm{E}\right)\end{array}$ \\
\hline PDGreenland & $\begin{array}{l}\text { As for experiment PDLabrador but with the negative anomaly only imposed over the NE Atlantic } \\
\left(52-72^{\circ} \mathrm{N}, 46^{\circ} \mathrm{W}-14^{\circ} \mathrm{E}\right)\end{array}$ \\
\hline LGMrelax & $\begin{array}{l}\text { Surface relaxation to CLIMAP (1981) annual sea surface temperatures and modern surface salinity } \\
\text { (+1 psu) fields, with wind stress from the annual averages of the LGM simulation of Hall et al. } \\
\text { (1996) }\end{array}$ \\
\hline LGMtopog & As for experiment LGMrelax, but with LGM coastlines and bathymetry \\
\hline LGMN & $\begin{array}{l}\text { LGM coastlines, bathymetry and initial raised salinity (by } 1 \mathrm{psu} \text { ), with surface ocean forced by the } \\
\text { annual average fields from the LGM simulation of Hall et al. (1996) }\end{array}$ \\
\hline LGMS & $\begin{array}{l}\text { As for experiment LGMN but with a positive precipitation anomaly of } 1 \mathrm{~mm} \text { per day imposed for } \\
500 \text { years over the North Atlantic }\left(42-75^{\circ} \mathrm{N}, 70^{\circ} \mathrm{W}-14^{\circ} \mathrm{E}\right)\end{array}$ \\
\hline
\end{tabular}

Table 2. Maximum zonally integrated meridional overturning volume stream function for the North Atlantic, North Pacific and the Southern Ocean adjacent to Antarctica and the volume transport through the Drake Passage and the Indonesian Throughflow for each experiment

\begin{tabular}{lccccc}
\hline $\begin{array}{l}\text { Experiment } \\
\text { label }\end{array}$ & $\begin{array}{c}\text { North } \\
\text { Atlantic }\end{array}$ & $\begin{array}{l}\text { North } \\
\text { Pacific }\end{array}$ & Antarctic & $\begin{array}{c}\text { Indonesian } \\
\text { Throughflow }\end{array}$ & $\begin{array}{c}\text { Drake } \\
\text { Passage }\end{array}$ \\
\hline PDrelax & 7.3 & 0.3 & 30.6 & 20.3 & 121.2 \\
PDSouth & 0.3 & 0.8 & 15.6 & 18.4 & 72.0 \\
PDLabrador & 28.0 & 1.0 & 8.3 & 23.5 & 45.1 \\
PDGreenland & 33.0 & 1.0 & 5.4 & 18.6 & 37.4 \\
LGMrelax & 32.2 & 2.0 & 2.8 & 17.0 & 39.3 \\
LGMtopog & 32.4 & 2.4 & 1.8 & 13.9 & 78.7 \\
LGMN & 55.7 & 0.9 & 12.1 & 9.7 & 73.6 \\
LGMS & 1.6 & 0.9 & & & \\
\hline
\end{tabular}

Values shown are the means for the last 500 years of each simulation, in Sverdrups $\left(10^{6} \mathrm{~m}^{3} \mathrm{~s}^{-1}\right)$.

formulae to calculate the longwave, sensible and latent heat fluxes, along with evaporation, as described by Bigg (1994). The ocean surface water balance is achieved without loss of salt (Huang 1993; Wadley et al. 1996), and includes runoff from land. The latter instantaneously flows down the steepest local gradient to the ocean. The heat flux scheme allows the fluxes to adjust to changes in ocean surface temperature but with an effective thermal coupling sensitivity $\left(20 \mathrm{~W} \mathrm{~m}^{-2} \mathrm{~K}^{-1}\right)$ which is much higher than in reality at the ocean basin scale ( $3 \mathrm{~W} \mathrm{~m}^{-2} \mathrm{~K}^{-1}$; Rahmstorf \& Willebrand 1995). The main consequences of this are in regions of high heat fluxes, such as locations of deep water formation, where surface ocean cooling is likely to be too high as each degree change in air temperature extracts almost seven times as much heat from the ocean as in reality. A fuller discussion of this issue can be found in Rahmstorf \& Willebrand (1995) and Bigg et al. (1998).

\section{Experimental description}

Eight different experiments were carried out to examine the sensitivity of the present-day and Last Glacial Maximum ocean to various climatic forcing factors (Table 1). Two of these, experiments, named 'LGMN' and 'LGMS', have been described in detail by Bigg et al. (1998). In this paper the attention will be focused on examining the large-scale differences between the simulations, and the dynamical consistency between the Last Glacial Maximum experiments and the observations discussed earlier. Note that all experiments were run with annual mean forcing to a stable state over at least 2000 years after initialization, or removal of any regional precipitation anomaly. In those experiments where such an anomaly was imposed, the precipitation field over the rest of the globe was altered appropriately, in a uniform fashion, so as to maintain the total global precipitation.

A global comparison between the different simulations is shown in Table 2. Experiment 'PDrelax' gives one Present Day benchmark against which to test the other models. As temperature and salinity are relaxed at the surface to modern climatologies, albeit with climate model wind fields forcing the surface rather than observed winds, it should be the closest of this set of experiments to the present-day ocean. The North Atlantic overturning in experiment PDrelax is about half the observed strength of 13-18 Sv (Schmitz \& McCartney 1993), with somewhat warm $\left(6^{\circ} \mathrm{C}\right.$ as opposed to $3.5^{\circ} \mathrm{C}$, Tomczak \& Godfrey 1994) North Atlantic Deep Water penetrating to about $2500 \mathrm{~m}$. A weaker upper-ocean circulation in the North Atlantic is associated with this weak overturning. The Antarctic Circumpolar Current, in contrast, is similar in strength to observations (Grose et al. 1995). The ocean convection is dominated by formation of Southern Component Water; convection occurs in the Weddell Sea, the Ross Sea and the Greenland Sea, as is consistent with observations. It should be noted that weak production of North Atlantic Deep Water is a feature of this type of ocean model, due to excessive mixing 
of the overflow water (Roberts et al. 1996). This also results in deep water that is too warm (England et al. 1992) and insufficient formation of intermediate waters. This accounts, for example, for the warm North Atlantic Deep Water seen in PDrelax. Antarctic Intermediate Water is also poorly represented without isopycnal mixing (England 1993). Bigg et al. (1998) discuss further reasons for differences between this experiment and reality. It should be borne in mind that this paper is about experimenting with ocean circulation modes, rather than trying to reproduce either present-day or Last Glacial Maximum reality.

Ceasing relaxation, and using the flux scheme mentioned above to force only the ocean surface with the various atmospheric model fields of the present-day control of Hall et al. (1996), leads to a very slightly greater freshwater input over the North Atlantic. The latter is essentially within the error bounds of observations (Wijffels et al. 1992), but has catastrophic consequences for North Atlantic overturning (experiment 'PDSouth'). The strength of the global thermohaline circulation is cut by $60 \%$ and deep convection only occurs, at a reduced rate, around the Antarctic. This experiment is similar to the southern sinking state of Marotzke \& Willebrand (1991). Also consistent with their experiments is the result of altering the freshwater balance in the North Atlantic in experiments 'PDLabrador' and 'PDGreenland'. By introducing a 500 year negative anomaly of $1 \mathrm{~mm}$ per day over the whole of the North Atlantic north of $42^{\circ} \mathrm{N}$ (experiment PDLabrador), a subsequently stable state with a somewhat enhanced thermohaline circulation ( $28 \mathrm{~Sv})$ is created, but with North Atlantic convection centred in the Labrador Sea, as is thought to happen periodically today (Dickson et al. 1996). Restricting the anomaly to the NE Atlantic (experiment PDGreenland) pushes the Atlantic convection into the Greenland Sea and further enhances the overall thermohaline circulation, although at the expense of the formation of less Southern Component Water. Either of these two states (simulations PDLabrador or PDGreenland) may be thought of as secondary benchmarks because they show how the MOM ocean model, under present-day surface forcing, responds to convection occurring in similar locations to reality. Thus, convection in the North Atlantic tends to be too strong relative to observations, while southern convection, and hence Southern Hemisphere circulation, tends to be too weak. This is worth remembering during our later discussion of Last Glacial Maximum simulations.

The state of the thermohaline circulation produced in these present-day experiments is critically dependent on where the densest surface water is found. While the atmospheric forcing and the dynamics of the topographically constrained ocean always tend to produce regional density maxima in similar locations, relatively minor perturbations to the distribution of the freshwater fluxes can alter which of these regional maxima becomes the global maximum. Once a location becomes a global convection centre a positive feedback develops where the ocean circulation alters to supply additional mass, salt and heat, to this location to sustain the convection. This restrains the available transport to other convection regions and lessens convection there. After a few decades it is possible to remove the anomaly which produces the new mode without affecting its stability. This is because a stable circulation pattern, which can sustain the new thermohaline structure, has been established. Note that it is possible to obtain a state with more than a single location of deep convection (e.g. experiments PDrelax or PDLabrador), although one always tends to be dominant.
The Last Glacial Maximum experiments can now be examined in the light of this sensitivity. Assuming the Hall et al. (1996) simulation is at least reasonably representative of the Last Glacial Maximum climate, our experiments should locate the potential regions of sub-thermocline water formation through examination of surface density extrema. Forcing the Last Glacial Maximum ocean to exist in different states, through forcing these different locations to become centres of deep convection, will delimit the dynamical characteristics with which palaeoceanographic observations can be compared.

Figure 3 shows the surface density-field for three Last Glacial Maximum simulations ('LGMtopog', 'LGMN', 'LGMS'). In experiment LGMrelax the surface temperature is relaxed to CLIMAP (1981) mean values, and the surface salinity is relaxed to the modern Levitus \& Boyer (1994) climatology $(+1$ psu to take account of the reduction in sea level), while the wind stresses from the Last Glacial Maximum simulation of Hall et al. (1996) provide the momentum flux. Experiment LGMtopog is identical to LGMrelax except that sea level was lowered by $120 \mathrm{~m}$. However, this, and the accompanying coastline changes, were of small importance as factors in climatic change (Table 2) so Fig. 3 only shows results from experiment LGMtopog and none from LGMrelax. Experiment LGMN is the Last Glacial Maximum equivalent of simulation PDSouth, despite the dominant convection occurring in opposite hemispheres in the two experiments. Thus in experiment LGMN the Last Glacial Maximum ocean is forced with the Hall et al. (1996) simulation. Experiment LGMS, like PDLabrador and PDGreenland, shows the stable state produced by a temporary freshwater anomaly, this time to the North Atlantic. Experiment LGMtopog (Fig. 3a) clearly shows the influence of the modern day salinity relaxation, as its convection region is north of the Greenland-Scotland Ridge, while both of the other experiments have their densest northern Atlantic water south of the ridge. The necessary, but insufficient, condition for deep convection at the Last Glacial Maximum is the occurrence of surface densities greater than $1028 \mathrm{~kg} \mathrm{~m}^{-3}$, in contrast to $1027.5 \mathrm{~kg} \mathrm{~m}^{-3}$ today. Thus experiments LGMtopog (Fig. 3a) and LGMN (Fig. 3b) have strong overturning within the Atlantic, while the simulation LGMS does not. Note, however, that the latter shows an overall two-thirds global decrease in overturning compared to the other two experiments. Each of these simulations also shows an extension of the northern dense water, with densities greater than $1027.5 \mathrm{~kg} \mathrm{~m}^{-3}$, along the European and NW African coast. In experiment LGMS (Fig. 3c) the positive freshwater anomaly initially applied north of $42^{\circ} \mathrm{N}$ meant that the northern convection was suppressed and shifted to the central North Atlantic, so that more salt remains in the sub-tropics, giving densities above $1028 \mathrm{~kg} \mathrm{~m}^{-3}$ off Iberia and NW Africa. Convection in these regions was also found in the Last Glacial Maximum ocean model of Seidov et al. (1996). The North Atlantic Deep Water in experiment LGMS is thus a mixture of cold fresh water from $50-55^{\circ} \mathrm{N}$ and warm salty water from the eastern sub-tropics. It therefore sinks to a shallower level than the North Atlantic Deep Water formed in either of the other two experiments (Fig. 4).

In the Pacific no region exceeds surface densities of $1026 \mathrm{~kg}$ $\mathrm{m}^{-3}$. This value is approached in the Sea of Okhotsk and off the west coast of South America but in no simulation is there more than a little upper intermediate water $(c .1000 \mathrm{~m})$ formed. The other potential convection location is around the Antarctic coast. Experiment LGMtopog shows some shallow convection in the Weddell and Ross Seas, essentially driven by 


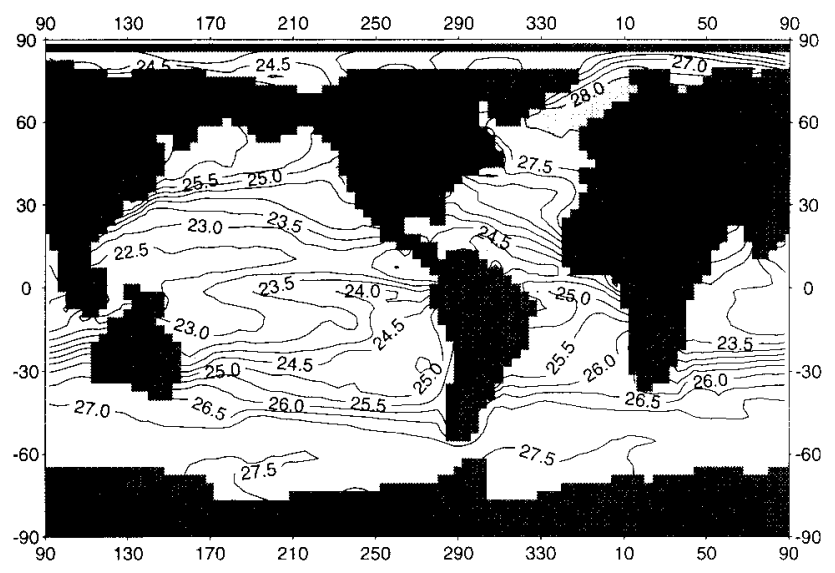

(a)

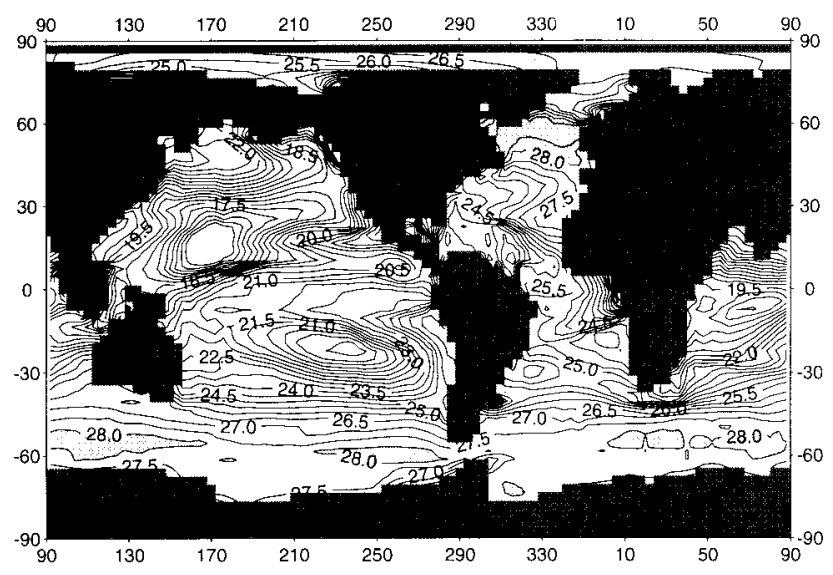

(b)

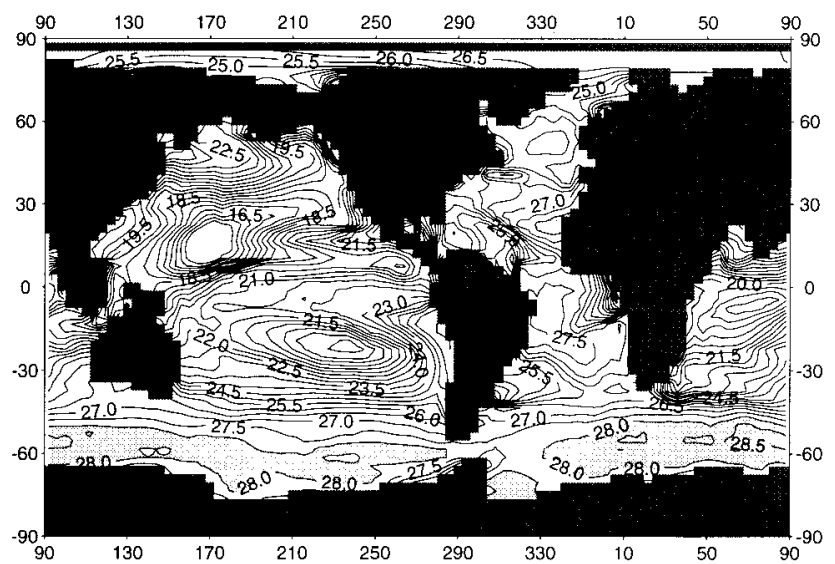

(c)

Fig. 3. Surface potential density (referenced to the surface) for experiments (a) LGMtopog, (b) LGMN, (c) LGMS. Contour interval is $0.5 \mathrm{~kg} \mathrm{~m}^{-3}$. Areas with density over $28.0 \mathrm{~kg} \mathrm{~m}^{-3}$ are shaded.

the imposition of modern salinity distributions. Deep convection in experiments LGMN and LGMS, in contrast, occurs away from the coast at the ice edge (Bigg et al. 1998), and preferentially in the southern Indian Ocean and the Bellinghausen Sea, west of Drake Passage. The former tends

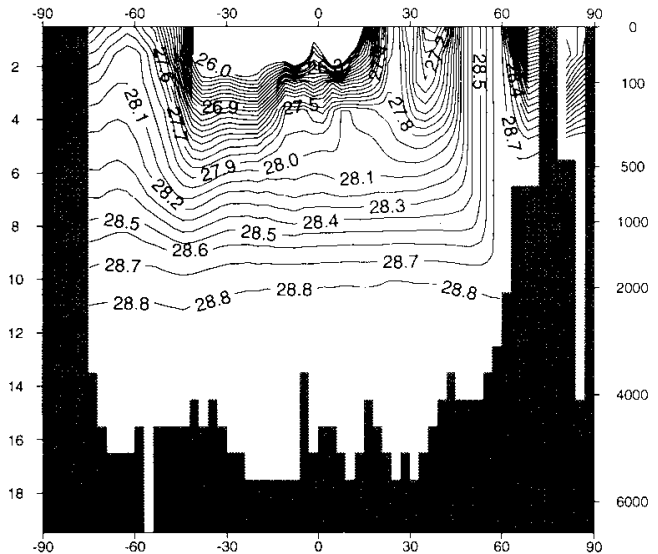

(a)

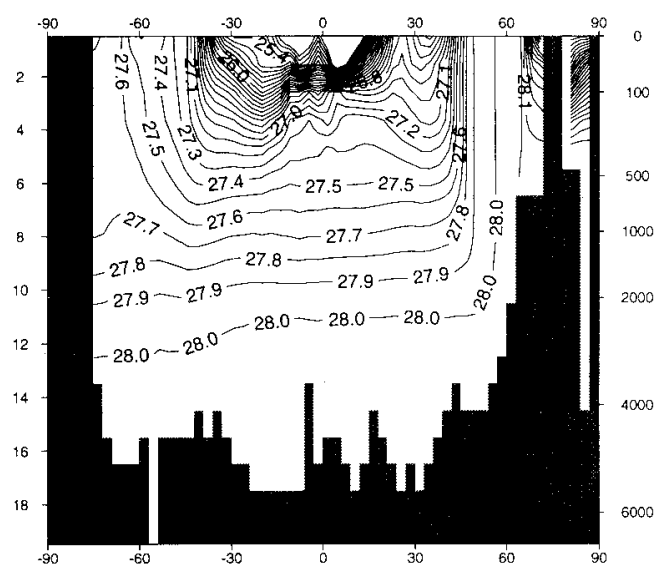

(b)

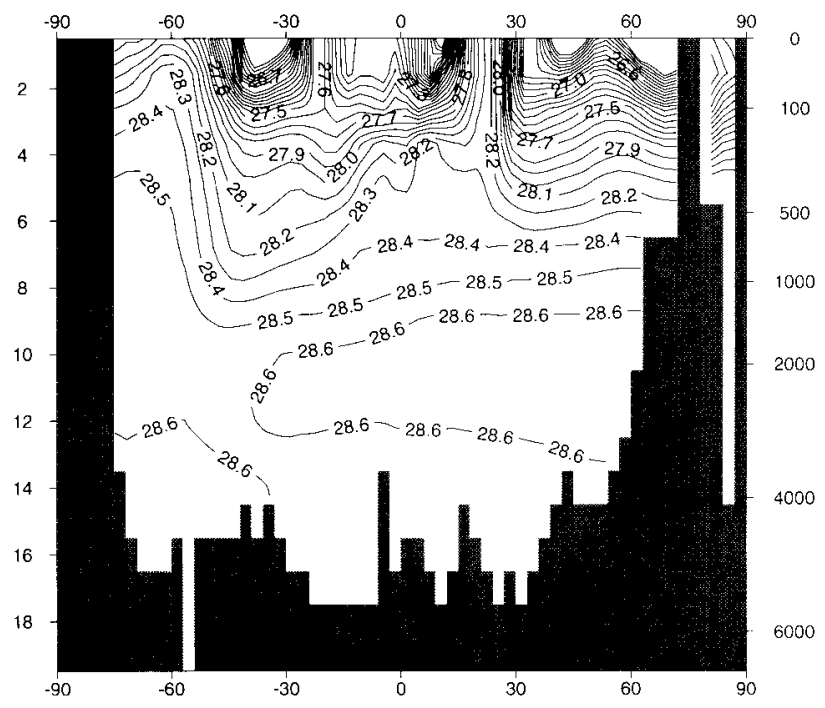

(c)

Fig. 4. Meridional cross-section of potential density (referenced to the surface) along $22^{\circ} \mathrm{W}$ for experiments (a) LGMtopog, (b) LGMN, (c) LGMS. Contour interval is $0.1 \mathrm{~kg} \mathrm{~m}^{-3}$. The Atlantic is in the centre of the cross-section. The model level is shown on the left and the approximate depth on the right axis. Only potential densities $>25.0 \mathrm{~kg} \mathrm{~m}^{-3}$ are shown. 
to be the dominant source of the two, supplying the Southern Component Water penetrating into the Atlantic at depth, particularly in experiment LGMS. In experiment LGMN much less Southern Component Water is formed so that the deep waters in the eastern basin of the Atlantic come from recirculation of the North Atlantic Deep Water through fracture zones in the Mid-Atlantic Ridge and the Cape Basin (Bigg et al. 1998).

\section{Discussion}

The experiments using a relaxation to CLIMAP sea surface temperatures with modern day surface salinities (simulations LGMrelax, LGMtopog) have very clear biases due to the salinity relaxation (Figs 3,4) and will be ignored in the following discussion. In a wide ranging comparison, covering surface conditions, iceberg trajectories as well as deep circulation, Bigg et al. (1998) showed substantial palaeoceanographic evidence consistent with circulation states found in either experiments LGMN or LGMS. On balance they favoured the northern convection state exhibited by experiment LGMN as being consistent with more palaeoceanographic data, but did not have the $\delta^{13} \mathrm{C}$ data-set described above to take into account. Neither state is likely to be truly representative of the Last Glacial Maximum ocean, just as none of the present day experiments truly reproduced the present-day ocean. However, it is likely that the Last Glacial Maximum general thermohaline circulation falls into either a predominantly North Atlantic Deep Water or Southern Component Water production state, just as the present-day experiments with significant North Atlantic Deep Water formation look better than those without this structure. We will consider the implications of the $\delta^{13} \mathrm{C}$ data in particular for the modelling.

A major difference in the deep ocean circulation between experiments LGMN and LGMS is in the Atlantic (Fig. 4). In experiment LGMN, North Atlantic Deep Water floods the entire basin. Nevertheless, as described by Bigg et al. (1998), examination of only the eastern Atlantic basin could lead to the conclusion that it is Southern Component Water that enters this basin because southward-flowing intermediate water overlies northward-flowing deep water here. This circulation is the now classical picture demonstrated by Duplessey et al. (1988) and Sarnthein et al. (1994). However, this Southern Component Water inflow is not what actually occurs in experiment LGMN. The source of the deep water is actually North Atlantic Deep Water from the western basin recirculating northwards through deep channels in the southern bathymetric barrier of the Cape Basin.

Having compiled transects of Last Glacial Maximum $\delta^{13} \mathrm{C}$ for both western and eastern basin (Fig. 1) examination of these two states can be re-assessed. The western transect (Fig. 1a) does show North Atlantic Deep Water penetrating into the Southern Ocean but it is underlain by water of very different nutrient properties - originating from the Southern Ocean. The hypothesis of a North Atlantic Deep Water re-circulation into the eastern basin is thus incompatible with the combined $\delta^{13} \mathrm{C}$ from both basins of the Atlantic. However, the density structure shown for experiment LGMS is consistent with the $\delta^{13} \mathrm{C}$ data. Thus, while near-surface conditions in experiment LGMS may be somewhat different from those experienced in the real Last Glacial Maximum ocean, because of the sensitivity of the ocean to the details of its surface forcing, sites of convection and the resulting dynamically balanced deep circulation should be comparable in more detail with palae-

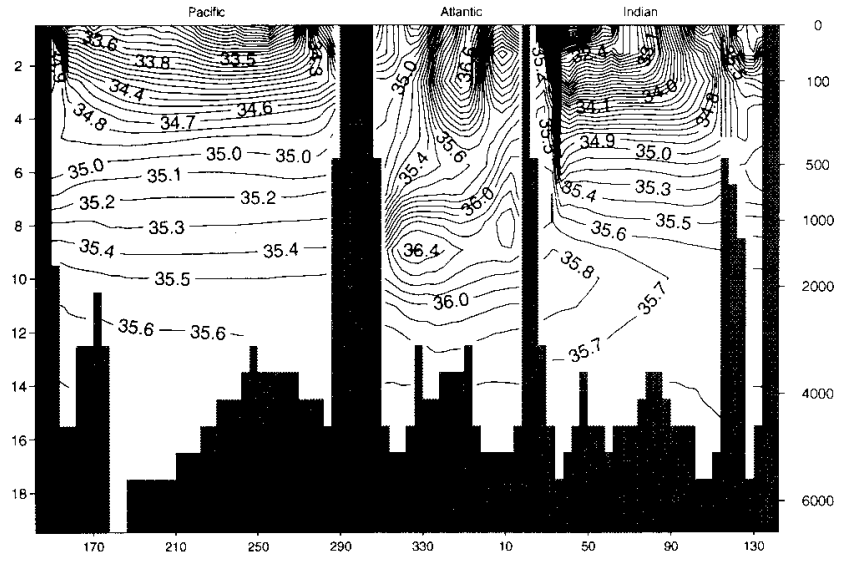

Fig. 5. Zonal cross-section of salinity along $33^{\circ} \mathrm{S}$ in experiment LGMS. Contour interval is $0.1 \mathrm{psu}$. The Atlantic is in the centre of the cross-section. The model level is shown on the left and the approximate depth on the right axis.

oceanographic data if the basic thermohaline structure of the Last Glacial Maximum ocean follows experiment LGMS.

A major characteristic of the $\delta^{13} \mathrm{C}$ data is the vertical boundary between North Atlantic Deep Water and Southern Component Water at a water depth of around $3500 \mathrm{~m}$, a similar level to this boundary in experiment LGMS (Fig. 4). The strength of North Atlantic Deep Water production at the Last Glacial Maximum is now thought to be broadly similar to that of today (Yu et al. 1996; Adkins \& Boyle 1997; Boyle 1997) but experiment LGMS shows a decline to about a quarter of that in the present-day benchmark simulation PDrelax (Table 2). However, the strength of Southern Component Water production declines by around a third in experiment LGMS, so the relative strength is only moderately decreased compared to experiment PDrelax, and consistent with the estimated $50 \%$ increase in lifetime of the Last Glacial Maximum Atlantic deep water, relative to today (Adkins \& Boyle 1997).

Three lesser features of the $\delta^{13} \mathrm{C}$ data that are of dynamical origin are the greater southward extent of the North Atlantic Deep Water in the western basin, the flow of western basin water into the east through the equatorial fracture zones and the upper intermediate water-flow northwards along the European margin. In Fig. 5 a cross-section of the experiment LGMS salinity field at $33^{\circ} \mathrm{S}$ is shown. High salinity water from the North Atlantic here spreads south above a water depth of $3000 \mathrm{~m}$, with a maximum in the western basin. Figure 5 also shows model evidence for penetration of North Atlantic Deep Water into the western Indian Ocean, as hypothesized from palaeoceanographic data by Boyle (1997). The Mid-Atlantic Ridge is not represented well in such a coarse model as discussed in this paper but flow through the Romanche Fracture Zone in experiment LGMS is directed from the western basin to the east throughout its depth (which is correctly represented). There is also a northward flow in experiment LGMS at a depth of $1000 \mathrm{~m}$ along the European margin, carrying the water formed in the sub-tropics northwards to be mixed with that derived from the central North Atlantic.

This paper has shown that the Atlantic thermohaline circulation properties of experiment LGMS are compatible with the distribution of $\delta^{13} \mathrm{C}$. We can therefore make inferences about the probable convection sites in the Last Glacial Maximum ocean. In the North Atlantic, experiment LGMS has convection off the eastern margin around $20-30^{\circ} \mathrm{N}$ and in the central 
North Atlantic around $20-30^{\circ} \mathrm{W}, 55-60^{\circ} \mathrm{N}$. In this experiment the former location is the most important, but minor changes to the surface heat and freshwater fluxes over the North Atlantic would alter the relative importance of these (e.g. see experiments LGMN or LGMtopog). Earlier discussion here has shown that convection SW of Iceland (Labeyrie \& Duplessey 1985; Sarnthein et al. 1995) and off NW Africa (Labeyrie et al. 1992; Sarnthein et al. 1994) are suggested in the palaeoceanographic data. This agrees with the LGMS simulation and here it is suggested that this experiment implies that other potential convection regions (in the NE Atlantic) are unlikely to have been active at the Last Glacial Maximum. It is worth noting that the convection site off NW Africa could have been enhanced by the de-stabilizing influence of the Mediterranean Outflow. It is believed that the Last Glacial Maximum transport of this water mass to the Atlantic was at the same flux (Zahn et al. 1987) as, or about half (Rohling 1991), that today. It may have been significantly saltier (Thunell \& Williams 1989), but more likely only slightly so (Bigg 1995). However, being colder at the Last Glacial Maximum, the outflow would have sunk to greater depth under either salinity re-construction (Bigg 1994). In the Southern Ocean, experiment LGMS supports the proposal by Michel et al. (1995) for open ocean convection in the Indian Ocean sector; it also suggests that the Bellinghausen Sea may reward exploration. An Indian Ocean source for the Southern Component Water in the Atlantic would also partly explain why its penetration into the eastern basin is greater than in the west.

\section{Conclusion}

This paper has explored the links between ocean model simulations, under different surface forcing regimes, and their compatibility with the Atlantic distribution of $\delta^{13} \mathrm{C}$, both today and at the Last Glacial Maximum. In particular, it has shown that a stable oceanic circulation can be produced by modelling that is consistent with many features of this palaeoceanographic data-set at the Last Glacial Maximum, even to quite fine detail. The convection locations shown by experiment LGMS link well with previous hypotheses and this data-set, while the relative strengths and depths of the two principal North Atlantic deep water masses predicted by observations are also compatible with this model experiment.

Both the $\delta^{13} \mathrm{C}$ data-set and ocean modelling of the Last Glacial Maximum are in their infancy. Beyond the Atlantic there is much less $\delta^{13} \mathrm{C}$ data available, and also relatively little available for other palaeoceanographic indicators. Key climatic questions such as the location of Southern Ocean convection, the fate of the Agulhas Current, the global influence of Heinrich events, and the presence of deep-water formation in the Pacific would be easier to address with more data from the other ocean basins. Similarly, ocean models need to be coupled to realistic atmospheric and sea-ice models to have any hope of a realistic, global, Last Glacial Maximum ocean circulation being simulated. Both of these aims are within reach in the coming decade, offering the potential for greater interaction between models and palaeoceanographic data in the future.

We thank P. Valdes of Reading University for providing the atmospheric forcing fields used in this study. The referees gave us useful advice for improving the manuscript. We also gratefully acknowledge financial support for this work by NERC through NEAPACC Special Topic grants GST/02/708 and GST/02/1179.

\section{References}

Adkins, J.F. \& Boyle, E.A. 1997. Changing atmospheric $\delta{ }^{14} \mathrm{C}$ and the record of deep water paleoventilation ages. Paleoceanography, 12, 337-344.

Berger, W.H. \& WeFER, G. 1996. Expeditions into the past: paleoceanographic studies in the South Atlantic. In: Wefer, G., Berger, W.H., Siedler, G. \& Webb, D.J. (eds) The South Atlantic: present and past circulation. Springer, Berlin, 363-410.

Bertram, C.J., Elderfield, H., Shackleton, N.J. \& Macdonald, J.A. 1995. Cadmium/Calcium and carbon-isotope reconstructions of the glacial northeast Atlantic-Ocean. Paleoceanogaphy, 10, 563-578.

Beveridge, N.A.S., Elderfield, H. \& Shackleton, N.J. 1995. Deep thermohaline circulation in the low-latitude Atlantic during the last glacial. Paleoceanography, 10, 643-660.

Bickert, T. \& Wefer, G. 1996. Late Quaternary deep water circulation in the South Atlantic: reconstruction from carbonate dissolution and benthic stable isotopes. In: Wefer, G., Berger, W.H., Siedler, G. \& WebB, D.J. (eds) The South Atlantic: present and past circulation. Springer, Berlin, 599-620.

BIGG, G.R. 1994. An ocean general circulation model view of the glacial Mediterranean thermohaline circulation. Paleoceanography, 9, 705-722.

1995. Aridity of the Mediterranean Sea at the last glacial maximum: a reinterpretation of the $\delta^{18} \mathrm{O}$ record. Paleoceanography, 10, 283-290.

—, Wadley, M.R., Stevens, D.P. \& Johnson, J.A. 1998. Simulations of two Last Glacial Maximum ocean states. Paleoceanography, 13, 340-351.

Boyle, E.A. 1992. Cd and ${ }^{13} \mathrm{C}$ paleochemical ocean distributions during the stage 2 glacial maximum. Annual Review of Earth and Planetary Science, 20, 245-287.

- 1997. Characteristics of the deep ocean carbon system during the past 150,000 years: $\Sigma \mathrm{CO}_{2}$ distributions, deep water flow patterns, and abrupt climate change. Proceedings of the National Academy of Sciences, 94, 8300-8307.

\& KeIGwin, L.D. 1987. North Atlantic thermohaline circulation during the last 20,000 years linked to high latitude surface temperature. Nature, 330, $35-40$.

— \& Rosenthal, Y. 1996. Chemical hydrography of the South Atlantic during the Last Glacial Maximum: Cd vs. $\delta^{13} \mathrm{C}$. In: WeFer, G., Berger, W.H., Siedler, G. \& WebB, D.J. (eds) The South Atlantic: present and past circulation. Springer, Berlin, 423-443.

Broecker, W.S. 1989. Some thoughts about the radiocarbon budget for the glacial Atlantic. Paleoceanography, 4, 213-220.

\& Peng, T.-H. 1982. Tracers in the Sea. Eldigio Press, Lamont-Doherty Geological Observatory, New York.

BRYAN, F. 1986. High-latitude salinity effects and interhemispheric thermohaline circulations. Nature, 323, 301-304.

CLIMAP 1981. Seasonal reconstruction of the Earth's surface at the last glacial maximum. Geological Society of America. Map Chart Series MC-36.

CURRY, W.B. 1996. Late Quaternary deep circulation in the western equatorial Atlantic. In: Wefer, G., Berger, W.H., Siedler, G. \& WebB, D.J. (eds) The South Atlantic: present and past circulation. Springer, Berlin, 577-598.

— \& Lohmann, G.P. 1982. Carbon isotope changes in benthic foraminifera from the western South Atlantic: reconstruction of glacial abyssal circulation patterns. Quaternary Research, 18, 218-235.

Dickson, R., Lazier, J., Meincke, J., Rhines, P. \& Swift, J. 1996. Long-term coordinated changes in the convective activity of the North Atlantic. Progress in Oceanography, 38, 241-295.

Duplessey, J.C., Shackleton, N.J., Matthews, R.K., Prell, W., Ruddiman, W.F., CaralP, M. \& Hendy, C. 1984. 13-C record of benthic foraminifera in the last interglacial ocean: implications for the carbon cycle and the global deep water circulation. Quaternary Research, 21, 225-243.

- — - Fairbanks, R.G., Labeyrie, L., Oppo, D. \& Kallel, N. 1988. Deepwater source variations during the last climatic cycle and their impact on the global deepwater circulation. Paleoceanography, 3, 343-360.

— L Labeyrie, L., Juillet-Leclerc, A., Maitre, F., Duprat, J. \& Sarnthein, M. 1991. Surface salinity reconstruction of the North Atlantic Ocean during the last glacial maximum. Oceanologica Acta, 14, 311-324.

ENGLAND, M.H. 1993. Representing the global-scale water masses in ocean general circulation models. Journal of Physical Oceanography, 23, 1523-1552.

—, TomczaK, M. \& Godfrey, J.S. 1992. Water-mass formation and Sverdrup dynamics: a comparison between climatology and a coupled oceanatmosphere model. Journal of Marine Systems, 3, 279-306.

FAIRBANKS, R.G. 1989. A 17000 year glacio-eustatic sea-level record-Influence of glacial melting rates on the Younger Dryas event and deep-ocean circulation. Nature, 342, 637-642.

Fichefet, T., Hovine, S. \& Duplessey, J.C. 1994. Thermohaline circulation of the Atlantic Ocean during the last glacial maximum. Nature, 372, 252-255. 
Grose, T.J., Johnson, J.A. \& BigG, G.R. 1995. A comparison between the FRAM (Fine Resolution Antarctic Model) results and observations in the Drake Passage. Deep-Sea Research, 42, 365-388.

Hall, N.M.J., Valdes, P.J. \& Dong, B.W. 1996. The maintenance of the last great ice sheets - a UGAMP GCM. Journal of Climate, 9, 1004-1019.

Hebbeln, D.T., Dokken, E.S., Andersen, M.H. \& Elverhoi, A. 1994. Moisture supply for northern ice-sheet growth during the Last Glacial Maximum. Nature, 370, 357-360.

Hillairemarcel, C., Devernal, A., Lucotte, M., Mucci, A., Bilodeau, G., Rochon, A., Vallieres, S. \& Wu, G.P. 1994. Carbon productivity and carbon flux in the Labrador Sea during the last 40,000 years. Canadian Journal of Earth Sciences, 31, 139-158.

HuANG, R.X. 1993. Real freshwater flux as a natural boundary condition for the salinity balance and thermohaline circulation forced by evaporation and precipitation. Journal of Physical Oceanography, 23, 2428-2446.

Imbrie, J., Boyle, E.A., Clemens, S.C. \& 15 Others 1992. On the structure and origin of major glaciation cycles; 1: linear responses to Milankovitch forcing. Paleoceanography, 7, 701-738.

KroopNick, P.M. 1985. The distribution of ${ }^{13} \mathrm{C}$ of $\Sigma \mathrm{CO}_{2}$ in the world oceans. Deep-Sea Research, 32, 57-84.

LabeYrie, L.D. \& Duplessey, J.C. 1985. Changes in the oceanic ${ }^{13} \mathrm{C} /{ }^{12} \mathrm{C}$ ratio during the last 140,000 years: high-latitude surface water records. Palaeogeography, Palaeoclimatology, Palaeoecology, 50, 217-240.

— - — Duprat, J., Juillet-Leclere, A., Moyes, J., Michel, E., Kallel, N. \& ShackLeton, N.J. 1992. Changes in the vertical structure of the North Atlantic Ocean between glacial and modern times. Quaternary Science Reviews, 11, 401-413.

Lautenschlager, M. \& Herterich, K. 1990. Atmospheric response to ice-age conditions - climatology near the Earth's surface. Journal of Geophysical Research, 95, 22 547-22 557.

_- Mikolajewicz, U., Maier-Reimer, E. \& Heine, C. 1992. Application of ocean models for the interpretation of atmospheric general circulation experiments on the climate of the last glacial maximum. Paleoceanography, 7, 769-782.

Levitus, S. \& Boyer, T.P. 1994. World Ocean Atlas 1994 Volume 3: salinity. NOAA NESDIS Atlas, Washington DC.

—, Burgett, R. \& Boyer, T.P. 1994. World Ocean Atlas 1994 Volume 4: temperature. NOAA NESDIS Atlas, Washington DC.

Mackensen, A., Hubberten, H.W., Bickert, T., Fischer, G. \& Fütterer, D.K. 1993. $\delta^{13} \mathrm{C}$ in benthic foraminiferal tests of Fontbotia wuellerstorfi (Schwager) relative to the $\delta^{13} \mathrm{C}$ of dissolved inorganic carbon in Southern Ocean deep water: implications for glacial ocean circulation models. Paleoceanography, 8, 587-610.

Manabe, S. \& Stouffer, R.J. 1995. Simulation of abrupt climate change induced by freshwater input to the North Atlantic Ocean. Nature, 378, 165-167.

ManighetTi, B. \& McCave, I.N. 1995. Late glacial and Holocene palaeocurrents around Rockall Bank, NE Atlantic Ocean. Paleoceanography, 10, $611-626$.

MarotzKe, J. \& Willebrand, J. 1991. Multiple equilibria of the global thermohaline circulation. Journal of Physical Oceanography, 21, 1372-1385.

Mercier, H., Speer, K.G. \& Honnorez, J. 1994. Flow pathways of bottom water through the Romanche and Chain Fracture-Zones. Deep-Sea Research, 41, 1457-1477.

Michel, E., Labeyrie, L., Duplessey, J.C., Gorfti, N., Labracherie, M. \& Turon, J.L. 1995. Hydrographic changes of the Southern-Ocean (southeast Indian sector) over the last $230 \mathrm{kyr}$. Paleoceanography, 11, 57-76.

OpPo, D. \& FairbanKs, R.G. 1987. Mid-depth circulation of the subpolar North Atlantic during the last glacial maximum. Earth and Planetary Science Letters, 86, 1-15.

Pacanowski, R.C., Dixon, K. \& Rosati, A. 1991. The GFDL Modular Ocean Model Users Guide, version 1.0. GFDL Ocean Group Techical Report No. 2, Princeton.

Peltier, W.R. 1994. Ice age paleotopography. Science, 265, 195-201.

RAHMSTORF, S. 1994. Rapid climate transitions in a coupled ocean-atmosphere model. Nature, 372, 82-85.

_ 1996. On the freshwater forcing and transport of the Atlantic thermohaline circulation. Climate Dynamics, 12, 799-811.

— \& England, M. 1997. Influence of Southern hemisphere winds on North Atlantic Deep Water flow. Journal of Physical Oceanography, 27, 2040 2054.

_ \& WiLLeBRAND, J. 1995. The role of temperature feedback in stabilizing the thermohaline circulation. Journal of Physical Oceanography, 25, 787-805.
Roberts, M.J., Marsh, R., New, A.L. \& Wood, R.A. 1996. An intercomparison of a Bryan-Cox type ocean model and an isopycnic ocean model. Part 1: the sub-polar gyre and high latitude processes. Journal of Physical Oceanography, 26, 1495-1527.

Robinson, S.G. \& MCCAVE, I.N. 1994. Orbital forcing of bottom-current enhanced sedimentation on the Feni Drift, NE Atlantic, during the mid-Pleistocene. Paleoceanography, 10, 221-250.

RoHLing, E.J. 1991. A simple two-layered model for shoaling of the eastern Mediterranean pycnocline due to glacio-eustatic sea level lowering. Paleoceanography, 6, 537-541.

Sarnthein, M., Jansen, E., Weinelt, M. \& 12 Others 1995. Variations in Atlantic surface ocean paleoceanography, $50^{\circ}-80^{\circ} \mathrm{N}-$ a time-slice record of the last 30,000 years. Paleoceanography, 10, 1063-1094.

_ W Winn, K., Jung, S.J.A., Duplessey, J.C., Labeyrie, L., Erlenkeuser, H. \& Ganssen, G. 1994. Changes in East Atlantic deep-water circulation over the last 30,000 years -8 time slice reconstructions. Paleoceanography, $\mathbf{9}$, 209-267.

Schmitz, W.J. \& McCartney, M.S. 1993. On the North Atlantic circulation. Reviews of Geophysics, 31, 29-49.

Seidov, D., Sarnthein, M., Stattegger, K., Prien, R. \& Weinelt, M. 1996. North Atlantic circulation during the last glacial maximum and subsequent meltwater event: a numerical model. Journal of Geophysical Research, 101, $16305-16332$.

Semtner, A.J. 1976. A model for the thermodynamic growth of sea ice in numerical investigations. Journal of Physical Oceanography, 6, 379-389.

Shackleton, N.S., Duplessey, J.C., Arnold, M., Maurice, P., Hall, M.A. \& CARTLIDGE, J. 1988. Radiocarbon age of the last glacial Pacific deep water. Nature, 335, 708-711.

SLOWEY, N.C. \& CuRRY, W.B. 1992. Enhanced ventilation of the North-Atlantic subtropical gyre thermocline during the last glaciation. Nature, 358, 665-668.

_ \& 1995. Glacial-interglacial differences in circulation and carbon cycling within the upper western North-Atlantic. Paleoceanography, 10, 715-732.

ThunelL, R.C. \& Williams, D.F. 1989. Glacial-Holocene salinity changes in the Mediterranean Sea: hydrographic and depositional effects. Nature, 338, 493-496.

TomcZaK, M. \& Godfrey, J.S. 1994. Regional Oceanography: an introduction. Pergamon, Oxford.

Tziperman, E. 1997. Inherently unstable climate behaviour due to weak thermohaline ocean circulation. Nature, 386, 592-595.

US Naval Oceanographic Office 1983. Digital Bathymetric Data Base5 minute grid. USNOO, Bay St Louis, Mississippi.

Veum, T.E., Jansen, E., Arnold, M., Beyer, I. \& Duplessey, J.C. 1992. Water mass exchange between the North Atlantic and the Norwegian Sea during the last 28,000 years. Nature, 356, 783-785.

Vidal, L., Labeyrie, L., Cortijo, E., Arnold, M., Duplessey, J.C., Michel, E., Becque, S. \& Van Weering, T.C.E. 1997. Evidence for changes in the North Atlantic Deep Water linked to meltwater surges during Heinrich events. Earth and Planetary Science Letters, 146, 13-27.

Wadley, M.R., BigG, G.R., Stevens, D.P. \& Johnson, J.A. 1996. Sensitivity of the North Atlantic to surface forcing in an ocean general circulation model. Journal of Physical Oceanography, 26, 1129-1141.

Webb, R.S., Rind, D.H., Lehman, S.J., Healy, R.J. \& Sigman, D. 1997. Influence of ocean heat transport on the climate of the Last Glacial Maximum. Nature, 385, 695-699.

Weber, M.E., Bonani, G. \& Fütterer, K.D. 1994. Sedimentation processes within channel-ridge systems, southeastern Weddell Sea, Antarctica. Paleoceanography, 9, 1027-1048.

Weinelt, M., Sarnthein, M., Pflaumann, U., Schulz, H., Jung, S. \& ERLENKeUSER, H. 1996. Ice-free Nordic Seas during the last glacial maximum? Potential sites of deepwater formation. Palaeoclimates, 1, 283-309.

Wijffels, S.E., Schmitt, R.W., Bryden, H.L. \& Stigebrandt, A. 1992. Transport of fresh water by the oceans. Journal of Physical Oceanography, 22, 155-162.

Yu, E.F., Francois, R. \& Bacon, M.P. 1996. Similar rates of modern and last-glacial ocean thermohaline circulation inferred from radiochemical data. Nature, 379, 689-694.

ZahN, R., WinN, K. \& SARntheIN, M. 1987. Benthic foraminiferal 13C and accumulation rates of organic carbon: Uvigerina peregrina group and Cibicidoides wullerstorfi. Paleoceanography, 1, 27-42. 